\title{
GROWTH AND YIELD PERFORMANCES OF EARLY RIPENING SUGARCANE CLONES ON INCEPTISOL SOIL
}

\author{
Abdurrakhman Abdurrakhman*, Djumali Djumali, Heliyanto Bambang, \\ Herwati Anik, Yulaikah Sri, Supriyono Supriyono \\ Balai Penelitian Tanaman Pemanis dan Serat, Indonesia \\ *E-mail: abdurrakhman2017@gmail.com
}

\begin{abstract}
High soil humidity in early ripening sugarcane causes low sugar yield. Early ripening sugarcane varieties such as PS 881 could not solve this problem. Some new early ripening sugarcane varieties have been known to generate more sugar yield PS 881 . This study was done to analyze the performance of early ripening sugarcane clones on Inceptisol soil in Karangploso Research Station, Malang, starting from May 2015 until August 2016. The study was arranged in a Randomized Block Design with four replications. The treatment involved five early ripening clones (PS 04 125, PS 05 124, PS 04 303, PS 06 204, and PS 06 395) and one control variety (PS 881). The results showed that PS 04125 clone obtained sugar yield $\left(8.51 \mathrm{t} \mathrm{ha}^{-1}\right)$ greater than PS 881 variety $\left(7.62 \mathrm{t} \mathrm{ha}^{-1}\right)$. PS 05124 , PS 06 204, PS 06 204, and PS 06395 clones obtained sugar yield $\left(7.71-7.88 \mathrm{t} \mathrm{ha}^{-1}\right)$ which was not significantly different from PS 881 variety. PS 04303 clone obtained sugar yield $\left(6.48 \mathrm{t} \mathrm{ha}^{-1}\right)$ lesser than PS 881 variety.
\end{abstract}

\section{KEY WORDS}

Growth, productivity, sugar content, sugar yield.

Sugar cane milling season in Indonesia occurs for 6-7 months, starting in May-June and ending in October-November. Rainfall accumulation 4 months before sugarcane harvest affects the actual sugar yield in sugar factories (Cardozo et al., 2015). High rainfall accumulation 4 months before the milling leads to moist soil. High soil moisture before the harvest decreases the value of brix and pol, reducing the sap value (Hossain et al., 2009 and Singh et al., 2012). High soil moisture causes a decrease in sugar yield (Loganadhan et al., 2012) which eventually causes lower actual sugar yield in sugar factory (Cardozo et al., 2015). Early harvest can also reduce the amount of maximum sugar yield (crystal yield) by 23.70-45.39\% (Viator et al., 2010).

The possibility of declines in sugarcane crystal yield can be anticipated in the beginning of the milling though certain arrangement of sugarcane varieties that produce high yields in high soil moisture conditions. Varieties that produce high yields under high humidity conditions are called early ripening varieties, while those that produce high yields under low humidity conditions are identified as slow ripening varieties. Whereas, sugarcane varieties that produce high yields under moderate humidity conditions are called moderate ripening varieties (Riajaya et al., 2016).

The ideal proportion of sugarcane arrangement in Indonesia is $30 \%$ early ripening varieties, $40 \%$ moderate ripening varieties and $30 \%$ slow ripening varieties. The early ripening varieties used in this study included PSCO 902, VMC 86-550, PS 863 and PS 881 with the potential for crystal yield of 8.52 each; 8.92; 9.23 and $9.58 \mathrm{t}$ ha-1. The potential crystal yield could not support the sugar self-sufficiency program. The potential crystal sugar yield is one of the factors affecting the success of sugar self-sufficiency program that it needs to be enhanced by applying new arrangement of high yielding varieties (Heliyanto et al., 2018).

The arrangement of new high yielding sugarcane varieties for early ripening sugarcane was carried out by producing 5 clones that potentially produce higher amount of crystal sugar yield. The five clones had to be compared with PS 881 to examine if they can outperform the yield produced by PS 881. On the other hand, sugarcane development in Indonesia is 
carried out on some different soil types, including inceptisol soil. This study determined the look of some superior early ripening sugarcane clones grown in inceptisol soil compared to PS 881.

\section{MATERIALS AND METHODS OF RESEARCH}

This study took place in KP. Karangploso Malang District from May 2015 to August 2016. Experiments were arranged using a randomized block design with 4 replications. The treatment involved 5 potential clones and one comparison variety (PS 881). The six treatments included (1) PS 04 125, (2) PS 05 124, (3) PS 04 303, (4) PS 06 204, (5) PS 06 395, and (6) PS 881. Each treatment was conducted using 8 rows with $10 \mathrm{~m}$ length and 110 $\mathrm{cm}$ PKP.

Manure at a dose of 5 tons $/ \mathrm{ha}^{-1}$, which is equivalent to $6.1 \mathrm{~kg}$ of each cage was used. The planting started in June 2015. The planting material was cut into two mules and then pretreated using pesticides. Two mules were planted in each row, with a total population of 20 mules per row.

Plant maintenance included seed sowing done 2 weeks after planting by planting the available seeds until reaching 20 plants per row.

Manuring was carried out at the age of 3-4 weeks after planting and 3 months after planting in the rows. Fertilizer at a dose of $400 \mathrm{~kg}$ Phonska $+600 \mathrm{~kg}$ ZA per hectare was applied. Phonska fertilizer ( $0.5 \mathrm{~kg}$ per hour) and ZA fertilizer ( $0.25 \mathrm{~kg}$ per hour) were given in the first fertilization, while the remaining ZA fertilizer $(0.5 \mathrm{~kg}$ per hour) was given at the second fertilization. Weeding was carried out 2 times simultaneously with manuring (I and II). Irrigation was carried out just before the manuring (there is no rain), while pest control was performed based on the level of pest attack.

Plant growth was observed by observing the number of stems, length of sections, stem length and diameter of the stem before harvest. Harvesting was done at 12 months of age. Observations were made by taking a sample of 1 family per row, in which 4 rows were taken per plot.

Productivity components were measured including the number and weight of the stems before harvest. The number of rods with minimum length of $150 \mathrm{~cm}$ was counted except for the side bars.

The yield was observed through squeezing-related factors, weight, and the value of sap before harvesting. Sample stems were squeezed with mills to extract the juice. The sap obtained was measured based on weight, brix and pol. Sugarcane productivity observation was carried out during harvest by weighing the harvested stems from all of the rows expect the ones located on the side. The squeezing factor (FP) was calculated based on the weight of the sap divided by the weight of the sample stem. Sap value (NN) was calculated using this following formula.

$$
\mathrm{NN}=0.4 \times(\text { brix }- \text { pol })
$$

Yield was measured using this following formula:

$$
\text { Yield }(\%)=\text { FP } \times \text { NN }
$$

Analysis of variance was performed to the obtained data using MSTAT version 5.1 software. The gaps in the treatments were identified using the Least Significant Difference Test with sig value set at $5 \%$.

\section{RESULTS AND DISCUSSION}

Growth. Internode length, number of internodes, length and stem diameter in inceptisol soil which were growth variables were influenced by the clones / varieties tested (Table 1). PS 04 125, PS 06204 and PS 06395 had larger internodes and PS 05124 had smaller 
internodes than PS 881. The length of sugarcane was influenced by plant genetics and environmental conditions (Junejo et al., 2010). Petel et al, 2014, suggested that plant genetic factors would affect the length of sugarcane knots under the same environmental conditions. Gomathi et al. (2013) stated that different stem lengths were due to different varieties used.

The clones / varieties used in inceptisol soil greatly influenced the number of internodes per growing sugarcane stem (Table 1). PS 05124 and PS 04303 clones produced more segments, while PS 04125 and PS 06395 clones produced lesser than PS 881. The genetic factors of plants affected the number of cane stem segments (Bonnett et al., 2006). As stated by Jamoza et al. (2014) and Djumali et al. (2018), differences in the number of stem segments produced are affected by genetic differences of the sugarcane.

Table 1 - Growth components of 5 superior sugarcane clones and comparator PS 881 on inceptisol soil

\begin{tabular}{ccccc}
\hline Clones / Varieties & $\begin{array}{c}\text { Segment length } \\
(\mathrm{cm})\end{array}$ & $\begin{array}{c}\text { Total segment } \\
\text { (Pieces) }\end{array}$ & $\begin{array}{c}\text { Stalk length } \\
(\mathrm{cm})\end{array}$ & Stalk diameter (mm) \\
\hline PS 04 125 & $15.22 \mathrm{a}$ & $16.82 \mathrm{~d}$ & $256.03 \mathrm{~cd}$ & $23.31 \mathrm{c}$ \\
PS 05 124 & $11.13 \mathrm{c}$ & $21.25 \mathrm{a}$ & $235.72 \mathrm{e}$ & $24.28 \mathrm{~b}$ \\
PS 04 303 & $12.74 \mathrm{~b}$ & $20.69 \mathrm{a}$ & $263.48 \mathrm{bc}$ & $24.45 \mathrm{~b}$ \\
PS 06 204 & $15.47 \mathrm{a}$ & $17.72 \mathrm{c}$ & $274.15 \mathrm{~b}$ & $22.52 \mathrm{~d}$ \\
PS 06 395 & $15.39 \mathrm{a}$ & $18.67 \mathrm{~b}$ & $287.49 \mathrm{a}$ & $21.27 \mathrm{e}$ \\
PS 881 & $12.95 \mathrm{~b}$ & $19.25 \mathrm{~b}$ & $249.34 \mathrm{~d}$ & $25.21 \mathrm{a}$ \\
\hline LSD 5\% & 0.55 & 0.79 & 0.71 & 0.71 \\
\hline
\end{tabular}

Note: Numbers accompanied by the same letter in one column means no significantly different in the $5 \%$ LSD test.

The length of sugarcane stalks was influenced by the clones / varieties used (Table 1). In PS 06 395, PS 06204 and PS 04303 longer stem lengths were obtained, while and PS 05124 had shorter stem lengths than PS 881 varieties. (Khan et al, 2012) found a positive correlation between stem length and the number of stem segments. PS 06395 and PS 06 204 clones produced longer stem lengths and PS 04303 produced more stem internodes compared to PS 881 variety, all of which had longer stem lengths than PS 881 . Streck et al. (2010) and Islam et al. (2011) also suggested that the genetic differences in the plants used would affect the length of the stems. The use of different varieties / clones affected the diameter of the sugarcane stalks as shown in (Table 1). The diameter of the stems produced by the clones tested did not match the PS 881 variety, even it had greater diameter. PS 06 395 produced the least stem diameter. Widyasari et al., (2009) explained that plant genetic factors and the environment affect the diameter of sugarcane stalks. Menossi et al., (2008) argued that in a homogeneous environmental condition, plant genetics would affect stem diameter. Whereas, Rahman et al. (2008) showed that the use of different sugarcane varieties resulted in different stem diameters.

Sugarcane Productivity. Sugarcane productivity covered stem weight and number of stems that were influenced by plant genetics (Table 2). PS 04303 produced the same stem weight as PS 881, while the other clones had lower ones, and the PS 06395 clone had the lowest one. There was a positive correlation between stem diameter and length and stem weight (Junejo et al., 2010; Shakoor-Ruk et al., 2014). The results of the study (Ghaffar et al., (2012) showed that the stem length parameters are the same, while the diameter of the stem affects the weight of the stem, and vice versa. The PS 06395 clone produced longer stem length, but the stem diameter was the smallest, resulting in the lowest stem weight. The results of this study are consistent with the ones of Chohan et al. al. (2014), stating that the use of different sugarcane varieties will result in different sugarcane stem weights.

The clones tested other than PS 04303 produced more stems than the PS 881 variety (Table 2). Ayeele and Tegene (2014) stated that genetic and environmental factors affect the number of sugarcane stalks per unit area produced. Dashora, (2012) also suggested that plant genetics in a uniform growing environment would affect the number of sugarcane stems. Widyasari et al. (2009) showed that the use of different sugarcane varieties resulted in a different number of stalks. 
The productivity of sugarcane in inceptisol soil is influenced by plants' genetic factors (Table 2). PS 06204 and PS 04125 produced slightly different productivity that PS 881 and PS 04 303, in which the productivity was at the lowest level. Stem weight and number of stems are the main components of sugarcane productivity (Soomro et al., 2012; Tyagi et al., 2013). Khalid et al., (2015) believe that higher sugarcane productivity is influenced by the number of stems and weight of sugarcane stalks. PS 06204 and PS 04125 clones produced lower stem weights and a large number of stems that the productivity was not quite different from PS 881 varieties with low productivity. The different properties of sugarcane varieties brought different productivity as stated by Kumar et al. (2012) and Zao et al. (2015). Similarly, Kumar et al. (2012) and Zao et al. (2015) also found similar phenomenon.

Table 2 - Stalk weights, number of stalks and productivity of 5 sugarcane clones and comparison of PS 881 on inceptisol soil

\begin{tabular}{|c|c|c|c|}
\hline Clones / Varieties & $\begin{array}{l}\text { Stalk weight } \\
\left(\mathrm{kg} \mathrm{stalk}^{-1}\right)\end{array}$ & $\begin{array}{c}\text { Total stalk } \\
\text { (stalk } \mathrm{m}^{-1} \text { row) }\end{array}$ & $\begin{array}{l}\text { Productivity } \\
\left(\mathrm{t} \mathrm{ha}^{-1}\right)\end{array}$ \\
\hline PS 04125 & $1.116 \mathrm{bc}$ & $9.84 b$ & $79.15 a b$ \\
\hline PS 05124 & $1.121 b$ & $8.79 c$ & $70.92 c$ \\
\hline PS 04303 & $1.280 \mathrm{a}$ & $6.76 \mathrm{e}$ & $62.32 d$ \\
\hline PS 06204 & $1.115 \mathrm{bc}$ & $10.23 a$ & $82.16 a$ \\
\hline PS 06395 & $1.043 c$ & $9.88 b$ & $74.22 b c$ \\
\hline PS 881 & $1.281 \mathrm{a}$ & $8.42 d$ & 77.67ab \\
\hline LSD 5\% & 0.071 & 0.11 & 6,91 \\
\hline
\end{tabular}

Note: Numbers accompanied by the same letter in one column are not significantly different in the 5\% LSD test.

Yield. Genetic factors of sugarcane affected the yield, including the milling yield and the percentage of the sap produced. (Table 3). The tested clones showed no different milling factor from the PS 881 variety, except for PS 06395 which produced less milling yield factor. Genetic and environmental factors influence the milling factors. (Inoue et al., 2009). Kuspratomo et al., (2012) also highlighted that plant genetics in a uniform growing environment will influence the milling factors, Smiullah et al. (2013) also proved that different sugarcane varieties resulted in different milling factors.

The clones tested in this study produced higher sap values, except for the PS 06204 clone which obtained similar value to PS 881 variety (Table 3). Singh et al., (2010) suggested that genetic factors and the uniformity of the environment for sugarcane will affect the value of sap for they are correlated (Kuspratomo et al., 2012). Smiullah et al. (2013) showed that differences in plant genetic factors bring different sap values.

The results of the observations (Table 3 ) show that the yield of sugarcane planted on inceptisol soil depended on the clones / varieties tested. The tested clones produced higher yields, except for PS 06204 clones which were not different from PS 881. This outcome support the statement (Khan et al., 2012) stating that milling factor and sap value correlate with yield. Similarly, Bahrani et al., (2009) and Keshavaiah et al., (2012) also state that the increase in yield is influenced by the increase in sap value and milling factors.

Table 3 - Sucrose content components, sucrose content potential and sucrose yield of 5 sugarcane clones and comparison of PS 881 on inceptisol soil

\begin{tabular}{|c|c|c|c|}
\hline Clones / Varieties & Juice extraction & Juice value & Juice Potency Sucrose yield (t ha $\left.{ }^{-1}\right)(\%)$ \\
\hline PS 04125 & $0.631 a$ & $17.11 \mathrm{~b}$ & $10.78 \mathrm{a} 8.51 \mathrm{a}$ \\
\hline PS 05124 & $0.652 a$ & $16.91 b$ & $11.00 a 7.82 b$ \\
\hline PS 04303 & $0.626 a$ & $16.63 b$ & $10.41 \mathrm{a} 6.48 \mathrm{c}$ \\
\hline PS 06204 & $0.622 a$ & $15.38 \mathrm{c}$ & $9.57 b 7.88 b$ \\
\hline PS 06395 & $0.566 \mathrm{~b}$ & $18.44 a$ & $10.41 \mathrm{a} 7.71 \mathrm{~b}$ \\
\hline PS 881 & $0.651 \mathrm{a}$ & $15.08 \mathrm{c}$ & $9.81 b 7.62 b$ \\
\hline LSD 5\% & 0.028 & 1.09 & 0.590 .43 \\
\hline
\end{tabular}

Note: Numbers accompanied by the same letter in one column mean that they are not significantly different in the $5 \%$ LSD test.

The clones PS 05 124, PS 04 125, and PS 04303 produced higher sap values, while the milling factors were not different from the PS 881 variety, resulting in more yields 
obtained. PS 06395 produced inadequate milling factor, but the sap value was greater, producing greater amount of yield than the PS 881 variety. As explained by Kuspratomo et al. (2012), differences in sugarcane varieties used lead to different amount of yield.

Crystal Yield. The crystal yield of sugarcane planted on inceptisol soil was influenced by the clones / varieties of the sugarcane (Table 3). PS 04125 produced higher crystal yield compared to PS 04 303, while the tested clones showed no differences from PS 881. Soomro et al., (2012) and Rehman et al., (2014) stated that sugarcane productivity and the sugarcane yield affect the amount of crystal yield. PS 04125 clones had similar productivity, but it produced higher yield, resulting in more amount of crystal yield compared to PS 881 . PS 04303 clones produced higher yields, but the productivity was much lower that the crystal yield was lower than PS 881 variety. Islam et al. (2011) argued that genetic varieties lead to differences in the crystal yield.

\section{CONCLUSION}

PS 04125 produced higher amount of crystal yield than PS 881. PS 05 124, PS 06 204, PS 06 204, and PS 06395 clones produced insignificantly different crystal yield than PS 881. Finally, the crystal yield produced by PS 04303 was found lesser than the one of PS 881.

\section{ACKNOWLEDGEMENTS}

Gratitude is expressed to the Head of Balai Penelitian Tanaman Pemanis dan Serat who has funded this research through DIPA of 2015. The researcher is thankful to the Head of Kebun Percobaan Karangploso and the Head of Laboratorium Kimia Tanaman who allowed and supported the implementation of this research and gratitude also goes to field technicians who also made this research accomplished.

\section{REFERENCES}

1. Ayeele, N., S. Tegene. 2014. Effect of number of buds per sett and ontra-row spacing of setts on yield and component of sugarcane. Int. J. Agric. Sci. Nat. Resources. 1: 115121.

2. Bahrani, M.J., M. Shomeili, S.H. Zande-Parsa, A. Kamgar-Haghighi. 2009. Sugarcane responses to irrigation and nitrogen in subtropical Iran. Iran Agric. Res. 27:17-26.

3. Bonnett,G.D., M.L. Hewitt, D. Glassop. 2006. Effect of high temperature on the growth and composition of sugarcane internodes. Australian J. Agric. Res. 57: 1087-1095

4. Cardozo, N.P., P.C. Sentelhas, A.R. Panosso, A.L. Palhares, B.Y. Ide. 2015. Modeling sugarcane ripening as a function of accumulated rainfall in Southern Brazil. Inter. J. Biometeorol 59: 1913-1925.

5. Chohan, M., U.A. Talpur, S. Junejo, G.S. Unar, R.N. Panhwar, B. Pa. 2014. Selection and evalution of the diverse sugarcane genotypes in 4th stage. J. Anim. Plant Sci. 24: 197-203.

6. Dashora, P. 2012. Productivity and sustainability of sugar (Saccharum officinarum) genotypes under planting seasons and fertility levels in south-east Rajasthan. Academia Arena 4: 37-41.

7. Djumali, B. Heliyanto, A.D. Khuluq. 2018. Evaluasi klon-klon tebu potensial di lahan kering. J. Agron. Indonesia 46: 328-336.

8. Ghaffar, A., Ehsanullah, N. Akbar, S.H. Khan, K. Jabran, R.Q. Hashmi, A. Iqbal, M.A. Ali. 2012. Effect of trench spacing and micronutrients on growth and yield of sugarcane (Saccharum officinarum L.). Aust. J. Crop. Sci. 6: 1-9.

9. Gomathi, R., P.N.G. Rao, D. Rakkyappan, B.P. Sundara, S. Shiyamala. 2013. Physiological studies on ratoonability of sugarcane varieties under tropical indian condition. American J. Plant Sci. 4: 274-281. 
10. Heliyanto, B., Djumali., Abdurrakhmanm, Damanhuri, N. R. Ardiarini. 2018. Uji daya hasil genotipe harapan tebu di lahan kering. Buletin Tanaman Tembakau, Serat dan Minyak Industri. 1: 32-38.

11. Hossain, S.M.I., S.U.K. Eusufzai, M.A. Rahman. 2009. Effect of different irrigation levels on growth and yield parameters of sugarcane. Pakistan J. Agric. Res. 22: 28-35.

12. Inoue, K., I. Yamane, T. Kaji. 2009. Effect of nitrogen topdressing and number off tillers at maximum tillering stage on the field and extract quality of ratoon sugarcane cultivar $\mathrm{Ni} 17$. Japanese J. Soil Sci. Plant Nutr. 80: 1-6.

13. Islam, M.S., M.A.S. Miah, M.K. Begum, M.R. Alam, M.S. Arefin. 2011. Growth, yield and juice quality of some selected sugarcane clones under water-logging stress condition. World J. Agric. Sci. 7: 504-11.

14. Jamoza, J.E., J. Owuoche, O. Kiplagat, W. Opile. 2014. Broad-sense heritability estimation and correlation among sugarcane (Saccharum spp. hybrids) yield and some agronomic traits in Western Kenya. Int. J. Agric. Pol. Res. 2: 16-25.

15. Junejo, S., G.M. Kaloi, R.N. Panhwar, M. Chohan, A.A. Junejo, A.F. Soomro. 2010. Performance of newly developed sugarcane genotypes for some qualitative an quantitative traits under thatta conditions. J. Anim. Plant Sci. 20: 40-43.

16. Keshavaiah, K.V., Y.B. Palled, C. Shankariah, H.T. Channal, B.S. Nandihalli, K.S. Jagadeesha. 2012. Effect of nutrient management practices on nutrient dynamics and performance of sugarcane. Karnataka J. Agric. Sci. 25:187-192.

17. Khan, I.A., S. Bibi, S. Yasmin, A. Khatri, N. Seema, A.S. Abro. 2012. Correlletion studies of the agronomic traits for higher sur yield in sugarcane. Pak J. Botany. 44: 969-971.

18. Kumar, N., H. Singh, R. Kumar, V.P. Singh. 2012. Productivity and profitability of different genotypes of sugarcane (Saccharum spp) as influenced by fertility levels and planting seasons. Indian J. Agron. 57: 180-185.

19. Kuspratomo, A.D., Burhan, M. Fakhry. 2012. Pengaruh varietas tebu, potongan dan penundaan giling terhadap kualitas nira tebu. Agrointek. 6: 123-132.

20. Loganandhan, N., B. Gujja, V.V. Goud, U.S. Natarajan. 2012. Suistanable sugarcane initative (SSI): a methodology of more with less. Sugar Tech. 14: 1-5.

21. Menossi, M., M.G. Silva-Filho, M. Vincentz, M.A.Van-Sluys, G.M. Souza. 2008. Sugarcane functional genomics, gene discovery for agronomic trait development. Int. J. Plant Genomics. 2008: 1-11.

22. Patel, D., V.C. Raj, B. Tandel, B. Patel, D.U. Patel, V. Surve. 2014. Influence of planting distance and variety on growth of sugarcane and weed population under mechanization. J. Inter. Academic. Res. Multidisc. 2: 34-41.

23. Rahman, M.A., S.U.K. Eusufzai, S.S. Tabriz, S.M.I. Hossain. 2008. Optimization of irrigation level for selected sugarcane varieties in AEZ-11 of Bangladesh. The Agriculturists. 6: 99-107.

24. Rehman, A., R. Qamar, J. Qamar. 2014. Economic assessment of sugarcane (Saccharum officinarum L.) through intercropping. J. Agric. Chem. Envir. 3: 24-28.

25. Shakoor-Ruk, A., M.N. Kandhro, S.K. Baloch, S. Ullah-Baloch, A. Bakhsh-Baloch. 2014. Impact of sett placement method and row directions on growth and yield of sugarcane variety LRK-2001. Persian Gulf Crop Protect. 3: 53-59.

26. Riajaya,P.D., Fitriningdyah T.K. 2016. Kesesuaian tipe kemasakan varietas tebu pada tipologi lahan bertekstur berat, tadah hujan dan drainase lancar. Buletin Tanaman Tembakau, Serat dan Minyak Industri. 2:88-98.

27. Singh, G.D., S.K. Saini, A. Bhatnagar, G. Singh. 2012. Effect of planting methods and irrigation scheduling on growth, yield and quality of spring planted sugarcane (Saccharum officinarum L.). Ann. Agric. Res. 33: 21-24.

28. Singh, N.P., R.D.N. Verma, R.G. Singh, S.B. Singh. 2010. Effect of planting geometry and nitrogen level on yield and juice quality of sugarcane. J. Sugar Tech. 2: 40-43.

29. Soomro, A.F., S. Tunio, F.C. Oad, I. Rajper, M.I. Khuhro, M.Y. Arain. 2012. Effect of supplemental inorganic NPK and residual organic nutrients on sugarcane ratoon crop. Inter. J. Sci. Eng. Res. 3: 1-11. 
30. Smiullah, F.A. Khan, U. ljaz, Abdullah. 2013. Genetic variability of different morphological and yield contributing traits in different accession on Saccharum officinarum L. Universal J. Plant Sci. 1: 43-48.

31. Streck, N.A., J.G. Hanauer, L.F. Gabriel, T.C. Buske, J.A. Langner. 2010. Leaf development and growth of selected sugarcane clones in a subtropical environment. Pesq. Agropec. Bras. 45: 1049-1057.

32. Tyagi, V.K., S. Sharma, S.B. Bhardwaj. 2013. Pattern of association among cane yield, sugar yield and their components in sugarcane (Saccharum officinarum L.). J. Agric. Res. 50: 29-38.

33. Viator, R.P., C.D. Dalley, R.M. Johnson, E.P . Richard. 2010. Early harvest affects sugarcane ratooning ability in Louisiana. Sugarcane International. 28: 123-127.

34. Widyasari, W.B., Damanhuri, E. Sugiyarta. 2009. Pengujian 20 klon koleksi tebu hibrida terhadap kondisi kekurangan air. MPG. 45: 1-18.

35. Zhao, D., B. Glaz, M.S. Irey, C.J Hu. 2015. Sugarcane genotype variation in leaf photosynthesis properties and yield as affected by mill mud application. Agron. J. 107: 506-514. 